Pacific Journal of Mathematics

REMARK ON THE USE OF FORMS IN VARIATIONAL 


\section{REMARK ON THE USE OF FORMS IN VARIATIONAL CALCULATIONS}

\section{LOUIS AUSLANDER}

In [1] we introduced in equation (2.2) the form

$$
\omega=\sum \frac{\partial F}{\partial q_{i}^{\prime}} d q_{i}-\left(\sum q_{i}^{\prime} \frac{\partial F}{\partial q_{i}^{\prime}}-F\right) d t .
$$

The purpose of this note is to explain the reason for introducing precisely this form.

We considered the integral

$$
I=\int_{a}^{b} F\left(q_{1}, \cdots, q_{n} ; q_{1}^{\prime}, \cdots, q_{n}^{\prime} ; t\right) d t .
$$

Now let $S$ be the set of all forms $\eta$ such that if $X$ denotes the vector field to a curve $C$ with equations

$$
\begin{aligned}
q_{i} & =q_{i}(t) \\
q_{i}^{\prime} & =\frac{d q_{i}}{d t} \\
t & =t
\end{aligned}
$$

Then $\langle X, \eta\rangle=F$ or $I=\int_{a}^{b}\langle X, \eta\rangle d t$. The set $S$ is certainly not void since $F\left(q_{1}, \cdots, q_{n} ; q_{1}^{\prime}, \cdots, q_{n} ; t\right) d t$ and $\omega$ are contained in it. We will prove the following.

THEOREM. There exists one and only one form $\omega$ in $S$ such that along every curve of the above type $\omega$ and $d \omega$ give rise to forms in the space $\left(q_{1}, \cdots, q_{n}, t\right)$.

Proof. The hypotheses of this theorem are equivalent to the following two analytic conditions:

1. $\left\langle\partial / \partial q_{i}^{\prime}, \omega\right\rangle=0$

2. $\left\langle\partial / \partial q_{i}^{\prime} \wedge \partial / \partial x, d \omega\right\rangle=0$ when $q_{i}^{\prime} d t=d q_{i}$ where $x$ is any of the coordinates $\left(q_{i}, q_{i}^{\prime}, t\right), i=1, \cdots, n$.

Condition 1. implies that $\omega=\Sigma a_{i} d q_{i}+b d t$. Now since $\omega \in S$ we must have

Received February 17, 1956. This paper was written while the author was a National Science Foundation Postdoctoral Fellow. 


$$
\sum a_{i} \frac{d q_{i}}{d t}+b=F \quad \text { or } \quad \omega=\sum a_{i} d q_{i}+\left(F-\sum a_{i} q_{i}\right) d t
$$

By computing $d \omega$ and replacing $q_{i} d t$ by $d q_{i}$ we get

$$
\frac{\partial F}{\partial q_{i}^{\prime}}=a_{i}
$$

This proves that $\omega=\sum \frac{F}{q_{i}^{\prime}} d q_{i}-\left(\sum \frac{F}{q_{i}^{\prime}} q_{i}^{\prime}-F\right) d t$ is the only form which satisfies the theorem.

\section{ReFERENCE}

1. Auslander, L., The use of forms in variational calculations, Pacific J. Math., 5 (1955), 853-859.

The Institute for Advanced Study 


\section{PACIFIC JOURNAL OF MATHEMATICS}

EDITORS

\author{
H. L. Royden \\ Stanford University \\ Stanford, California \\ E. Hewite \\ University of Washington \\ Seattle 5 , Washington
}

\author{
R. P. Dilworth \\ California Institute of Technology \\ Pasadena 4, California
}

\author{
A. Horn* \\ University of California \\ Los Angeles 24, California
}

\section{ASSOCIATE EDITORS}
E. F. BECKENBACH
M. HALL
M. S. KNEBELMAN
J. J. STOKER
C. E. BURGESS
P. R. HALMOS
I. NIVEN
V. GANAPATHY IYER
T. G. OSTROM
G. SZEKERES
H. BUSEMANN
R. D. JAMES
M. M. SCHIFFER
F. WOLF
H. FEDERER

\section{SPONSORS}

\author{
UNIVERSITY OF BRITISH COLUMBIA \\ CALIFORNIA INSTITUTE OF TECHNOLOGY \\ UNIVERSITY OF CALIFORNIA \\ CALIFORNIA RESEARCH CORPORATION \\ MONTANA STATE UNIVERSITY \\ UNIVERSITY OF NEVADA \\ OREGON STATE COLLEGE \\ UNIVERSITY OF OREGON \\ UNIVERSITY OF SOUTHERN CALIFORNIA
}

\author{
STANFORD UNIVERSITY \\ UNIVERSITY OF UTAH \\ WASHINGTON STATE COLLEGE \\ UNIVERSITY OF WASHINGTON \\ AMERICAN MATHEMATICAL SOCIETY \\ HUGHES AIRCRAFT COMPANY
}

Mathematical papers intended for publication in the Pacific Journal of Mathematics should be typewritten (double spaced), and the author should keep a complete copy. Manuscripts may be sent to any of the editors. Manuscripts intended for the outgoing editors should be sent to their successors. All other communications to the editors should be addressed to the managing editor, Alfred Horn at the University of California, Los Angeles 24, California.

50 reprints of each article are furnished free of charge; additional copies may be obtained at cost in multiples of 50 .

The Pacific Journal of Mathematics is published quarterly, in March, June, September, and December. The price per volume (4 numbers) is $\$ 12.00$; single issues, $\$ 3.50$. Back numbers are available. Special price to individual faculty members of supporting institutions and to individual members of the American Mathematical Society: $\$ 4.00$ per volume; single issues, $\$ 1.25$.

Subscriptions, orders for back numbers, and changes of address should be sent to Pacific Journal of Mathematics, c/o University of California Press, Berkeley 4, California.

Printed at Kokusai Bunken Insatsusha (International Academic Printing Co., Ltd.), No. 10, 1-chome, Fujimi-cho, Chiyoda-ku, Tokyo, Japan.

* During the absence of E. G. Straus.

PUBLISHED BY PACIFIC JOURNAL OF MATHEMATICS, A NON-PROFIT CORPORATION COPYRIGHT 1956 BY PACIFIC JOURNAL OF MATHEMATICS 


\section{Pacific Journal of Mathematics}

\section{Vol. 6, No. $2 \quad$ December, 1956}

Louis Auslander, Remark on the use of forms in variational calculations .......................................... 209

Hubert Spence Butts, Jr. and Henry B. Mann, Corresponding residue systems in algebraic number fields ........................ 211

L. Carlitz and John Herbert Hodges, Distribution of matrices in a finite field............................................

Paul Civin and Bertram Yood, Invariant functionals ............... 231

David James Dickinson, Henry Pollak and G. H. Wannier, On a class of polynomials orthogonal over a denumerable set .................

Bernard Friedman and Luna Mishoe, Eigenfunction expansions associated with a non-self-adjoint differential equation ....................

Luna Mishoe and G. C. Ford, On the uniform convergence of a certain eigenfunction series .............................. 271

John W. Green, Mean values of harmonic functions on homothetic curves...........................................

Charles John August Halberg, Jr. and Angus E. Taylor, On the spectra of linked operators .....................................

Chuan Chih Hsiung, Some integral formulas for closed hypersurfaces in Riemannian space ................................... 291

Norman D. Lane, Differentiable points of arcs in conformal n-space 301

Louis F. McAuley, A relation between perfect separability, completeness, and normality in semi-metric spaces

G. Power and D. L. Scott-Hutton, The slow shearing motion of a liquid past a semi-infinite plane .............................

A. C. Schaeffer, Entire functions

Edward Silverman, An intrinsic inequality for Lebesgue area...

Choy-Tak Taam, Asymptotic relations between systems of differential equations.

Ti Yen, Quotient algebra of a finite $A W^{*}$-algebra ... 